This item was submitted to Loughborough's Research Repository by the author.

Items in Figshare are protected by copyright, with all rights reserved, unless otherwise indicated.

\title{
Working the boundaries in the motor industry
}

PLEASE CITE THE PUBLISHED VERSION

PUBLISHER

(C) IMechE / Professional Engineering Publishing

VERSION

VoR (Version of Record)

LICENCE

CC BY-NC-ND 4.0

REPOSITORY RECORD

Smart, P.K., N.J. Brookes, F.E. Lettice, C.J. Backhouse, and Neil D. Burns. 2019. "Working the Boundaries in the Motor Industry". figshare. https://hdl.handle.net/2134/4586. 
This item was submitted to Loughborough's Institutional Repository (https://dspace.lboro.ac.uk/) by the author and is made available under the following Creative Commons Licence conditions.

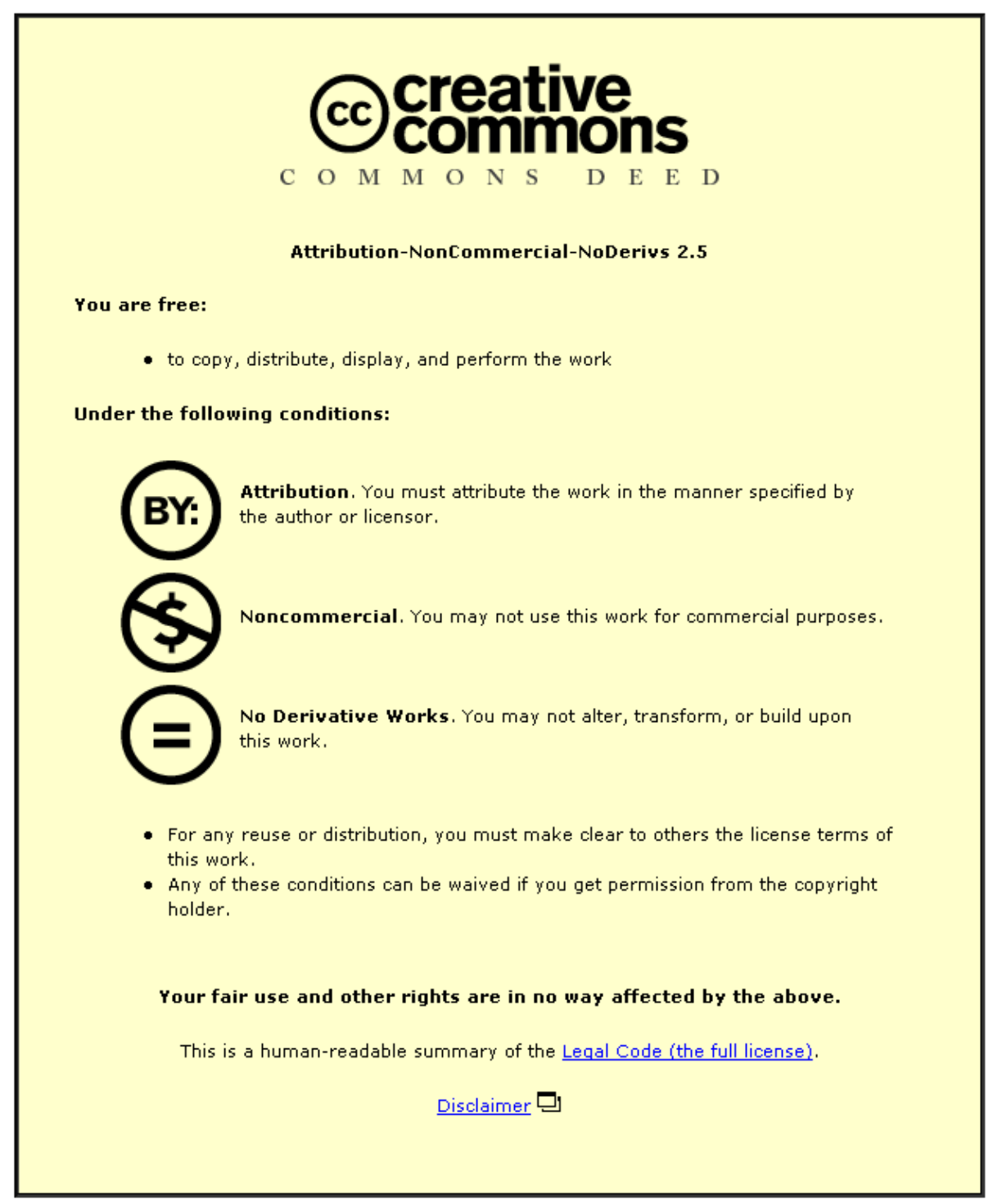

For the full text of this licence, please go to: http://creativecommons.org/licenses/by-nc-nd/2.5/ 


\title{
Working the boundaries in the motor industry
}

\author{
P K Smart*, N J Brookes, F E Lettice, C J Backhouse and N D Burns \\ Department of Manufacturing Engineering, Loughborough University, Loughborough, UK
}

\begin{abstract}
Improving product development performance, through changes in organizational structure, has been an important goal for many researchers, organizational development consultants and industrialists in the 1990s. The challenges of the twenty-first century business environment will require a radical re-think of old ideas about formal organizational structures and their impact on company achievements. Perhaps it is time to question whether the choice of any one organizational structure over another is really conducive to improvements in product development performance. The 'Working the Boundaries' Project will undertake an investigation into the feasibility of a boundary-based view to product development in the automotive industry. This paper sets the research context and presents some preliminary research findings in the form of a 'tentative theory' that suggests the importance of the informal organization based on the network of interrelationships between product developers.
\end{abstract}

Keywords: boundaries, product development, formal organization, informal organization, networks

\section{INTRODUCTION}

\subsection{The 'Working the Boundaries' Research Project}

The 'Working the Boundaries' research is a collaborative project undertaken by Loughborough University, Engineering and Physical Sciences Research Council (EPSRC) and the British arm (Company A) of a German automobile manufacturer. It addresses a problem germane to all manufacturing sectors where product development activity is valued as significant. This involves an investigation of the dilemmas experienced by companies when deciding how to organize for product development. Whether it be a 'team' or 'function' based environment, fundamental principles behind an organization's structural design need to be reconsidered.

Until recently the implementation of multidisciplinary teams has been recognized as a means of rapidly improving the way product development activities are managed [1-4]. However, a project team approach to organizing product development activity is not without its ills. These can be categorized as follows:

1. The 'functional rump'. Not all product development functions and activities can be placed in a project team. This may be because either they are not large enough to justify a project team or they use resources

\footnotetext{
The MS was received on 28 April 2000 and was accepted after revision for publication on 10 May 2000.

* Corresponding author: Department of Manufacturing Engineering, Loughborough University, Loughborough, Leicestershire LE11 $3 T U$, $U K$.

that are so scarce that they cannot be spread across project teams. In both cases a significant portion of product development activities are denied the benefits of a project-based organization.

2. Organizational learning. Project-based organizations may inhibit organizational learning. Functional specialists allocated into project teams gradually lose their distinguishing features. The detailed knowledge that they originally held becomes diluted and out-of-date with the inevitable effect on design quality and product cost [5]. The organizational barriers that once prevented the communication of project priorities have now been re-drawn to prevent communications in and out of projects. Francis and MacIntosh [6] succinctly express this:

Moving from a wholly function-based organisation to a wholly process-based organization would simply be the equivalent of moving from vertical to horizontal walls or barriers.

If there are advantages and disadvantages associated with both project and functional organizations, then it may be supposed that there is some optimal point for product development lying along the spectrum between them. Companies may feel that if they could identify this then their organizational problems would be over and they could enjoy the benefits of both function and team-based structures while reducing the problems to a minimum.

However, research by Henderson [7] from the Sloan Management Institute at the Massachusetts Institute 
of Technology indicates that searching for this 'optimal' point is a fruitless exercise. This work, based in the pharmaceutical industry, indicates that it is not the type of organization structure adopted by companies that governs their product development success. It is the ability of the company to overcome the boundaries of any organizational grouping in a fashion that dictates the company's achievements. Henderson states that:

Success (in product development) is not a function of a particular organisational choice. Indeed the most successful companies in our study were those that were never satisfied with any single answer.

In the terms of the organizational theorists Lawrence and Lorsch's [8] landmark study, it is not the method of differentiation that ensures success but the methods of integration.

Drucker [9] has recently echoed the belief in the pointlessness of searching for one organizational form:

Implicit is a change in the very meaning of the word organisation. For more than a century - from J. P. Morgan and John D. Rockefeller in the United States, George Siemens in Germany, Henri Fayol in France through Alfred Sloan at GM and up to the present infatuation with teams - we have been searching for one 'right' organisation for our companies. There can no longer be any such thing.

If these findings hold true for the wider product development environment, then they may have radical implications. A boundary-based view of product development would argue that the success shown by project-based teams was not due to their project focus per se but to their ability to integrate with the rest of the organization. It would mean that the 'functional rump' could operate with a similar degree of effectiveness as the rest of the product development organization if appropriate mechanisms for overcoming the organizational boundaries were put in place. It would also mean that the problems of organizational learning associated with a project-based structure could be overcome by an appropriate choice of mechanisms.

This project seeks to corroborate these propositions in a different industrial environment to that of Henderson's original study by carrying out a longitudinal case study with an automotive company. The objectives of the project are as follows:

(a) to identify potential mechanisms for 'Working the Boundaries' within product development;

(b) to incorporate these mechanisms into a preliminary tool that would assist individual companies in determining which methods for 'Working the Boundaries' would be most appropriate for their specific circumstances;

(c) to identify a way forward for further development and testing of the tool.
A hybrid research methodology strategy is being used to gain an in-depth evaluation of the experiences of Company A. It focuses on gaining this knowledge from an empirical investigation of product development practices. The research process uses structured and semistructured questionnaire surveys and face-to-face interviews to gather both qualitative and quantitative data from the research sample. The investigation is both exploratory and descriptive, aiming to provide holistic and meaningful interpretations of real-life events in their natural settings. The explorative component identifies the boundaries and the mechanisms for overcoming them. A complementary descriptive element uses case study data to illustrate why boundaries and mechanisms exist and to a lesser extent how organizations can overcome them successfully. Together this will help to generate a novel theory and supporting conceptual model, to portray the relationships between the 'boundaries' and 'mechanisms' and to show how they may serve to improve product development performance.

The following section sets the research context and presents some preliminary findings.

\section{SETTING THE RESEARCH CONTEXT}

\subsection{The impact of organizational structure on product development project performance}

Organizations have traditionally been predominantly vertical structures. Over the last 30 years many organizations have attempted to alter their structures and the hierarchy they entail, but most have ended up with a form reminiscent of the traditional vertical structure.

The coming of age of mass production with Fordism (1863-1947) and the development of Adam Smith's (1776) fundamentals by Taylor in Scientific Management (1913) show the deep division and specialization of labour [10]. Mass production was seen to de-humanize the nature of work in exchange for a wage. During the early part of the twentieth century Western manufacturing companies diffused their organizational structures towards specialized functions. Work alienation showed the rise of individuals that lacked opportunities to expend imagination, intellect and responsibility. Working environments were characterized by a lack of flexibility and coordination and integration between the different functional departments. Since the mid-1970s inroads have been made into eradicating Taylorism from the blue-collar work environment. The current fascination for re-engineering is increasingly tackling the whitecollar business sector in an attempt to narrow the gap between an organization's management and its employees to create a seamless organization operating around its core areas of competency and business vision and goals. Some of these characteristics are described in Ashkenas et al.'s Boundaryless Organisation [11]. 
Sloan, the President of General Motors in 1923-1966, instigated the creation of the multidivisional form. This form was an attempt to balance the forces of centralization and decentralization [10]. The 1960s saw the emergence of problems with organizational bureaucracy and emphasis on cost cutting, leading to powerful domination of functions like finance; such systems of organizational structure were being associated with a decline in organizational performance.

In 1967 Lawrence and Lorsch [8] conducted seminal research into how environmental factors influence internal organizational structure. They suggest there is no one best way to organize in all environmental situations. Pace of technology change in the market economy at global levels requires organizations to change. Stable organizations tended to be more mechanistic and rely heavily on forms and procedures. Organizations in the more dynamic industry were more organic. In these organizations the span of supervisory controls was wider, there was less attention to formal procedures and more decisions were made in the middle levels of the organization. The organic nature of organization was a view proposed by Burns and Stalker back in $1961[\mathbf{1 0}]$.

Today's post-Fordist era is increasingly being characterized by organizations that do not want to create a non-human monolith, producing narrow product portfolios, with little choice for customers and poor customer service. Increasingly work is organized in a more organic way, susceptible to rapid continuous but sometimes discontinuous change. There are also many examples of organizations that have benefited from this method of operation and now stand as role models (e.g. GE, AT\&T, Chrysler, Toyota and Microsoft) for the international business community.

\subsection{The focus of recent competitive product development strategies}

A modern culture in the Western world presents the challenge of constant change. Developed societies are faced with an era of uncertainty where change is fast becoming a natural part of social, economic and political life $[12,13]$. From an industrial perspective, this dynamism induces changes in organizational strategy, structure, policy, technologies, processes and the way people think and behave at work to impact product development performance.

Senior management within manufacturing organizations is increasingly recognizing this urgent need to embrace such changes. A positive response to the demands of change will help to secure their competitive position in both domestic and global markets in the long term [14]. Holmes [15] in his report entitled 'Europe 2000', a survey based on 500 companies, portrayed global competition as reality for 50 per cent of those surveyed. This was expected to rise to 75 per cent by the year 2000. As global trading environments are changing and are extremely competitive and dynamic, organizations are looking to adopt state-of-the-art practices to achieve a sustainable competitive position.

The emergence of intense international competition; the creation of fragmented markets populated by demanding sophisticated customers; and diverse transforming technological change have combined to push new product development to the centre of the playing field in the competitive game (Clark and Fujimoto [16], p. 1).

The focus of recent competitive strategies is improvement in product development performance through the integration of different functional skills, knowledge and expertise. Integration is especially important during the early stages of a product's life cycle where most of its future cost is determined $[\mathbf{1 7}, \mathbf{1 8}]$.

However, Sobek et al. [19], in their study of Toyota, discuss the problems associated with achieving integration using teams. Although cross-functional coordination has improved, depth of knowledge within individual functions has decreased. Standardization across products had suffered because project teams have become too autonomous. They show how Toyota combines a highly formalized system with a number of 'twists' to ensure that each project is flexible and benefits from other projects.

Song et al. [20] suggest that new product success may be more likely when a firm employs functional-specific and stage-specific patterns of cross-functional integration than when it attempts to integrate all functions throughout the new product development stages. In opposition, Griffin's paper [21] presents an update of the new product development practices. She found that better firms used cross-functional teams for both more and less innovative projects.

The focus of today's competitive product development strategies like re-engineering is increasingly integration. This concept is becoming increasingly multifaceted in its application to product development activity. Grover's study [22] of re-engineering projects shows the importance of non-technology management issues concerning strategy, change and people. Such research findings are echoed in the foundations of this collaborative 'Working the Boundaries' Research Project.

\subsection{World motor industry}

The Massachusetts Institute of Technology (MIT) International Motor Vehicle Programme (IMVP) has reported high levels of global competition in the automotive industry. The results of this study have been presented in the Machine that Changed the World [23] and Product Development Performance [24]. Recent claims are that the maturity of West European, North American and Japanese markets leave little room for 
further growth. As a reaction to this some key players in the auto trade, such as General Motors (GM), Fiat and the BMW Group, are investigating investment opportunities in the Second World regions such as Eastern Europe, Latin America and Asia. While car sales are still rising on a global scale, opportunities for greater competition and investments (e.g. transplant or collaborative production) await exploitation.

On a global basis the industry is currently experiencing a period of over capacity. This may be one of the reasons for the many mergers and acquisitions, leading to a rationalization of product ranges. Although the First World markets are maturing, they are also becoming increasingly fragmented. Combined with high levels of competition and new technologies, the business environment has become extremely volatile. Product development activity is being carried out under greater levels of market uncertainty. More varied and sophisticated customer demands are leading to increasing product development complexities.

To ensure product development success, automotive companies have used a myriad of business improvement programmes. Some of the more recent programmes have included re-engineering, platform engineering $[\mathbf{2 5}, \mathbf{2 6}]$ and brand management [27]. In many cases these improvements are accompanied with the restructuring of organizations to meet the demands of the everchanging automotive markets better.

\subsection{Company A}

Company A remained one of the most profitable UK organizations until 1965. In 1966 it became a wholly owned subsidiary of the Leyland Motor Corporation. In 1968 Leyland Motor Corporation took over British Motor Corporation [28]. The new British Leyland Motor Corporation (BLMC) was a massive organization incorporating all UK motor manufacturers.

Financial problems struck BLMC in a succession of crises from 1973. It had lost money from most of its models, which were beginning to age in a declining market. The company had over-stretched itself in an attempt to become large enough to withstand competitors from Europe and Japan and increasingly from Ford and Vauxhall in the United Kingdom. These events were unfortunately compounded by the oil crises, the scare of a three-day working week and inflation rises. Pre-tax profits had gone from $£ 68$ million in 1973 to losses of $£ 16$ million in the first half of 1974.

In December 1974 Company A invited government intervention, which resulted in a parliamentary study 'British Leyland: The Next Decade'. It suggested that the government would support BLMC's expansion plans so long as severe product and market rationalization was carried out.
In 1977 a new Chief Executive Officer (CEO) set to work, following the recommendations of the parliamentary report. He initiated a 13-year collaborative product development relationship with a Japanese motor manufacturer. This relationship was characterized by a large injection of design capability by the Japanese partner. The CEO's departure in 1982 was preceded by the return of power to management to focus on new models for the markets. His successor re-established the current trading name for the firm. In 1989 Company A was sold to BAe and there was another change in the CEO position. In 1990 Company A made a profit of $£ 33$ million. In 1993 there were pre-tax profits of $£ 56$ million, which included the $£ 100$ million sale of Company A assets to Unipart.

It generally costs between $£ 1000$ and $£ 1500$ million to design and develop a new model from scratch and takes four to five years to generate sufficient funds to finance a replacement vehicle. As Company A had made little or no cash surplus for the last 20 years, the rate and extent to which new models could be replaced and redesigned had therefore been limited.

Company A, through its partnership with a Japanese manufacturer, had gained a glimpse of world leading edge manufacturing. As the last British car manufacturer, in 1994 British Aerospace (BAe) sold it to a German motor manufacturer. Only recently had Company A emerged out of its Japanese partner's shadow. The recent launch of Company A's sedan and midrange models has seen the beginning of a complementary product range. The mid-range models are being planned for replacement in 2002. Until very recently Company A was an integrated part of its German parent organization. Today its future is uncertain.

In 1996 the German parent company launched a reengineering initiative to improve product development performance. The 'Working the Boundaries' project team is working alongside the Re-engineering Section in the Research and Development function to investigate the following hypothesis:

\begin{abstract}
Manufacturing organizations that acquire and exercise capabilities to overcome boundaries in their organizational structure can improve product development performance.
\end{abstract}

\section{PRELIMINARY RESEARCH FINDINGS}

Preliminary findings from this project based on research into Company A's product development process and performance are now becoming apparent and are supporting Henderson's viewpoint of organizational boundaries. Further findings are also becoming evident and are echoing the experience of work in this area [29]. These initial findings are summarized in Sections 3.1 and 3.2. 
Table 1 Changes in organizational structures

\begin{tabular}{ll}
\hline $\begin{array}{l}\text { Changes in organizational structure } \\
\text { within product development }\end{array}$ & Time period \\
\hline $\begin{array}{l}\text { Functional to lightweight matrix } \\
\text { Lightweight to heavyweight matrix to } \\
\text { project team }\end{array}$ & $\begin{array}{l}\text { Approx. 1980-1990/1 } \\
\text { Project team to lightweight matrix }\end{array}$ \\
\hline
\end{tabular}

\subsection{Changes in organizational structure}

Over the last 20 years Company A's organization has undergone three primary changes in organizational structure. These are shown in Table 1 according to their respective time periods.

The primary purpose of Company A's organization structural changes has always been an attempt to improve its competitive advantage. Over this period of time an interesting pattern has arisen between the formal organizational structure adopted at a strategic and policy level and that which was implemented at an operational level, in the running of product development projects. It became apparent that to a greater or lesser degree of sophistication 'interdisciplinary' working or de facto teamworking was occurring at the operational level, informally, throughout the three different time periods.

\subsection{Tentative theory}

1. At Company A formal organizational boundaries arose as a result of the 'division of labour' of the product development task.

2. The formal organizational boundaries underwent three major repositionings between 1980 and 1999. However, minor changes to the formal organizational structure continued throughout this entire period.

3. There was a consistent presence of an informal organization' that continued its existence independently from changes in Company A's formal organization.

4. It was difficult to establish the relationship between the position of formal organizational boundaries and project success due to the existence of the informal organization.

5. Company A's informal organization developed in response to the changes in the nature of the product development task activity (increasingly specialized, complex, uncertain and interdependent). These changes required greater levels of interaction between engineering areas.

6. The informal organization enabled the efficient and effective temporary repositioning of formal boundaries. Project success appeared to be a function of this repositioning.
7. This informal organization appeared to be selfgenerating, self-organizing and self-managing.

8. The ability to reposition formal boundaries temporarily was also a function of individual skills and motivations.

Therefore:

9. Despite a series of changes in the formal organizational structure, the same core 'informal' organizational network was consistently engaged in product introduction and was reported as being a significant contributor to successful product development. This implies that improving product development performance cannot rely upon changing the formal organizational structure, but needs to make explicit recognition of existing informal networks.

10. Changing the position of the boundary cannot overcome formal organizational boundaries. Surmounting the boundary and hence improving information flow is a function of not only the repositioning of the boundary but the individual's capability and motivation to overcome it. This implies that attempts to improve product development cannot only address formal organizational structure but also needs to address an individual's capabilities and motivations.

Work is now under way to further validate and develop these initial findings. They will eventually be embodied in a prototype tool. The tool will enable organizations to utilize a full gamut of approaches in harnessing both formal and informal organizational structures and an individual's capability and motivation to improve product development performance. Future research will seek to ensure that the findings are 'generic' across different industrial sectors and not just confined to the Company A experience. This can be complemented by research efforts to develop and validate the tool within a wider research sample.

\section{ACKNOWLEDGEMENTS}

The authors would like to thank everyone at Company A Group who has participated in the research process. Without their kind efforts this work would not have been possible.

\section{REFERENCES}

1 Backhouse, C. J. and Brookes, N. J. Concurrent Engineering: What's Working Where, 1996 (Design Council/Gower).

2 Lettice, F. E. Concurrent engineering: a team-based approach to rapid implementation. $\mathrm{PhD}$ thesis, The CIM Institute, School of Industrial and Manufacturing Science, Cranfield University, 1995. 
3 Shina, S. G. (Ed.) Successful Implementation of Concurrent Engineering Products and Processes, 1994 (Van Nostrand Reinhold, New York).

4 Syan, C. S. and Menon, U. Concurrent Engineering: Concepts, Implementation and Practice, 1994 (Chapman and Hall, London).

5 Siemieniuch, C. E. and Sinclair, M. A. Ergonomic issues in organisational knowledge management and their implications for job design. Int. J. of CIM (accepted).

6 Francis, A. and MacIntosh The market, technological and industry context of business process re-engineering in the UK. Int. J. Ops Prod. Managmt, 1997, 17(4), 344-364.

7 Henderson, R. Managing innovation in the information age. Harvard Business Rev., January 1994, Reprint 94105.

8 Lawrence, P. R. and Lorsch, J. W. Oganisation and Environment: Managing Differentiation and Integration, 1967 (Harvard University School Press, Boston, Massachusetts).

9 Drucker, P. The future that has already happened. Harvard Business Rev., September-October 1997, 75(5), 20-24.

10 Crainer, S. Key management ideas. In Thinkers that Change the Management World, 1996 (Pitman Publishing, London).

11 Ashkenas, R., Ulrich, D., Jick, T. and Kerr, S. The Boundaryless Organisation: Breaking the Chains of Organisational Structure, 1995 (Jossey-Bass).

12 Phillips, N. Managing International Teams, 1992 (Pitman Publishing, London).

13 Johnson, M. Managing in the Next Millennium, 1995 (Butterworth Heinemann, Oxford).

14 Millson, M. R., Raj, S. P. and Wilemon, D. A survey of major approaches for accelerating new product development. J. Product Innovation Managmt, 1992, 9, 53-69.

15 Holmes, G. Europe 2000. EIU Research Report, The Economist Intelligence Unit, London, 1994.

16 Clark, K. B. and Fujimoto, T. Product Development Performance-Strategy, Organisation and Management in the World Auto Industry, 1991 (Harvard Business School Press, Boston, Massachusetts).

17 Smith, P. G. and Reinertsen, D. G. Developing Products in Half the Time, 1991 (Van Nostrand Reinhold, New York).
18 Shenas, D. G. and Derakhshan, S. Organisational approaches to the implementation of simultaneous engineering. Int. J. Ops Prod. Managmt, 1994, 14(10), 30-43.

19 Sobek, D. K., Liker, J. K. and Ward, A. C. Another look at how Toyota integrates product development. Harvard Business Rev., July-August 1998.

20 Song, M., Thieme, R. J. and Xie, J. The impact of crossfunctional joint involvement across product development stages: an exploratory study. J. Product Innovation Managmt, 1998, 15, 289-303.

21 Griffin, A. PDMA research on new product development practices: updating trends and benchmarking best practices. J. Product Innovation Managmt, 1997, 14(6).

22 Grover, V. From business reengineering to business process change management: a longitudinal study of trends and practices. IEEE Trans. Engng Managmt, February 1999, 46(1), 36-46.

23 Womack, J., Jones, D. and Roos, D. Machine that Changed the World, 1990 (Rawson Associates, New York).

24 Clark, K. B., Chew, B. and Fujimoto, T. Manufacturing for design: beyond the production/R\&D dichotomy. In Integrating Design and Manufacturing for Competitive Advantage (Ed. G. I. Susman), 1992, Ch. 11 (Oxford University Press, New York).

25 Cusamano, M. A. and Nobeoka, K. Thinking Beyond Lean: How Multi-project Management is Transforming Product Development at Toyota and Other Companies, 1998 (The Free Press).

26 Tatikonda, M. V. An empirical study of platform and derivative product development projects. J. Product Innovation Managmt, 1999, 16(3-6), 3-26.

27 Ward, S., Light, L. and Goldstine, J. What high-tech managers need to know about brands. Harvard Business Rev., July-August 1999.

28 Pilkington, A. Transforming Rover: Renewal Against the Odds 1981-1994, 1996 (Bristol Academic Press).

29 Krackhardt, D. and Hanson, J. R. Informal Networks: A Company Behind the Chart, 1993 (Harvard Business School Press, Boston, Massachusetts). 